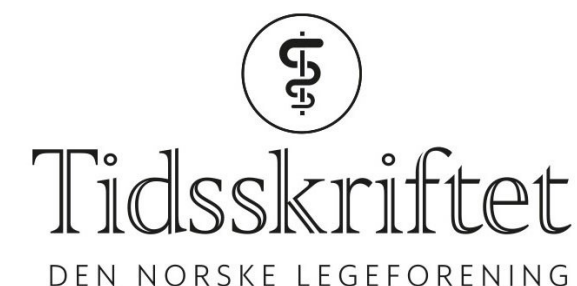

DEN NORSKE LEGEFORENING

\title{
Tor Drevvatne
}

MINNEORD

HANS HENRIK LIEN

ARNE HEILO

INGEBORG TAKSDAL

MARIT MURI HOLMEN

KRISTIAN TALLE

Tor Drevvatne var født i Oslo 10.11.1924 og døde på Bærum sykehus 2.12.2019. Han tok medisinsk embetseksamen i Oslo i 1951. Hans store tekniske interesse førte ham til spesialiteten diagnostisk radiologi. Etter en grundig spesialistutdannelse kom han til Radiumhospitalet i 1966. Der var han avdelingssjef fra 1979 til 1995.

Faget radiologi gjennomgikk en rivende utvikling i hans tid, og han frydet seg som et barn over mammografi, angiografi, CT, ultralyd og MR. Hans innsikt bidro til at han foretok kloke valg ved innkjøp av nytt utstyr, til beste både for den faglige utviklingen og for avdelingens og sykehusets økonomi. På internasjonale kongresser var han spesielt interessert i den tekniske delen og ble ofte tatt for å være sykehusfysiker. Allerede på 196otallet hadde han ideen til en "pathfinder», et nyttig verktøy ved angiografi, men dessverre tok ingen av maskinprodusentene sjansen på å sette den i produksjon. Ideen var imidlertid forløperen for digital subtraksjonsangiografi, som ofte benyttes i dag.

Tor Drevvatne så potensialet til sine yngre kolleger. Hans kvalitetskrav stimulerte til innsats, og han tildelte hver enkelt de oppgavene de hadde best forutsetning for å fylle. Derved fikk han en velfungerende avdeling med praktisk anlagte leger til intervensjonsarbeidet og de mer teoretisk anlagte til den avanserte billedtolkningen. I midten av 1980-årene satte han unge, datainteresserte kolleger på oppgaven å utvikle et pasientadministrativt system for røntgenavdelingen. Dette var billig og tjente avdelingen godt inntil 2003, da større, svært dyre sykehussystemer overtok.

Hans administrative evner kom til sin rett i en rekke tillitsverv i Norsk radiologisk forening og Nordisk Forening for Medicinsk Radiologi. Han var æresmedlem i begge foreninger.

Som sjef tok Tor Drevvatne godt vare på sine ansatte. Han stilte seg selv i bakgrunnen og gledet seg alltid over andres fremgang. De tre siste tiår slet han med sykdom, men hans arbeidsglede og faglige engasjement gjorde at han holdt det gående innen mammografiscreeningen til han var nesten $8 \mathrm{o}$ år. 
Privat trivdes han best hjemme med sine nærmeste. Vi minnes Tor Drevvatne med glede og takknemlighet. Tankene går til hans solide støttespiller gjennom 68 år, Randi, og til resten av hans lille familie.

Tidligere kolleger ved Radiologisk avdeling, Radiumhospitalet

Publisert: 24. februar 2020. Tidsskr Nor Legeforen. DOI:10.4045/tidsskr.20.0042

(C) Tidsskrift for Den norske legeforening 2020. Lastet ned fra tidsskriftet.no 